\title{
INTERAKSI PARTISIPATIF ANTARA PENYULUH PERTANIAN DAN KELOMPOK TANI MENUJU KEMANDIRIAN PETANI
}

\author{
Joni Jafri ${ }^{1}$, Rudi Febriamansyah ${ }^{2}$, Rahmat Syahni $^{3}$, dan Asmawi ${ }^{4}$ \\ RINGKASAN \\ Penyuluhan pertanian (PP) menjadi penting sebagai upaya menuju \\ kemandirian petani. Dengan berlakunya UU no 16 tahun 2006, tentang Sistem \\ Penyuluhan Pertanian, Perikanan dan Kehutanan (UU SP3K), maka PP didorong \\ untuk lebih partisipatif, dengan mengarahkan pada pendekatan yang lebih demand \\ driven. Kondisi tersebut akan tercapai apabila PP dapat memenuhi kebutuhan dan \\ masalah sasaran (pelaku utama dan pelaku usaha), melalui interaksi partisipatif. \\ Interaksi yang tidak partisipatif akan menyebabkan sasaran PP menjadi kehilangan \\ prakarsa, inisiatif bahkan kehilangan jati diri, karena kurang menyentuh pada kapital \\ manusia (human capital). Interaksi partisipatif antara penyuluh pertanian dengan \\ petani yang ada dalam kelompok merupakan hubungan yang saling mempengaruhi \\ dalam upaya meningkatkan kapasitas, namun kondisi tersebut belum terwujud \\ sesuai dengan harapan. \\ Penelitian ini bertujuan; (1) Mengetahui dan menganalisa faktor internal dan \\ eksternal penyuluh yang membentuk kapasitas penyuluh pertanian untuk melakukan \\ interaksi partisipatif dengan kelompok tani dalam upaya mendorong kemandirian \\ petani. (2) Mengetahui dan menganalisa faktor internal dan eksternal kelompok tani \\ yang membentuk kapasitas kelompok tani dalam melakukan interaksi partisipatifnya \\ dengan penyuluh dalam upaya mendorong kemandirian petani, dan (3) Mengkaji \\ keterkaitan kapasitas penyuluh pertanian dan kapasitas kelompok tani dalam proses \\ interaksi partisipatif antar keduanya. \\ Penelitian dilakukan di Kabupaten kabupaten Merangin dan Kabupaten \\ Kerinci, provinsi Jambi. Setiap kabupaten dipilih secara acak enam kecamatan, dan \\ setiap kecamatan dipilih tiga desa, dengan demikian ada 36 desa sampel dengan 36 \\ penyuluh, Untuk setiap penyuluh dipilih secara acak dua kelompok yang diwakili \\ satu pengurus dan dua anggota sehingga jumlah sampel petani 144 orang. Dengan \\ demikian total jumlah sampel adalah 190 orang.
}


Disain penelitian menggunakan dua pendekatan yaitu pendekatan kuantit atif dan kualitatif. Analisis kualitatif menggunakan pendekatan deskriptifinduktif, dan analisis kuantitatif menggunakan program PLS (Partial Least Square). Metoda analisa Partial Least Square (PLS) termasuk dalam kelompok Structural Equation Modeling (SEM) berbasis variance atau component based

Hasil penelitian menunjukkan; (1) Interaksi partisipatif dipengaruhi oleh kapasitas penyuluh pertanian dan kapasitas kelompok tani, pengaruh kapasitas kelompok tani lebih tinggi dibanding kapasitas penyuluh pertanian. (2) Kapasitas penyuluh pertanian dipengaruhi oleh faktor internal dan faktor eksternal. Faktor internal dicirikan oleh: kompetensi andragogik, kompetensi komunikasi, kompetensi mengembangkan kelompok, dan kompetensi sosial. Faktor eksternal dipengaruhi oleh dukungan inovasi, kebijakan penyuluhan, struktur organisasi penyuluh, dan sarana prasarana penyuluhan.(3) Kapasitas kelompok tani dipengaruhi oleh faktor internal dan faktor eksternal. Faktor internal dicirikan oleh struktur kelompok, kekompakan/kebersamaan, efektivitas kelompok, dan karakteristik individu petani. Faktor eksternal dipengaruhi oleh sistem pembinaan, sosial budaya, dan sarana prasarana. (4) Interaksi partisipatif dicirikan oleh indicator yang berasal dari unsur kelompok tani, yaitu: proses motivasi kelompok tani, proses interaksi kelompok tani, dan proses strukturisasi kelompok tani.

Temuan teoritis dari penelitian ini adalah bahwa padigma penyuluhan pertanian harus digeser dari kegiatan yang didominasi proses mendidik, mengajar, dan mentransfer inovasi menjadi penyuluhan yang berorientasi penggerak perubahan dan mengembangkan inovasi dari dalam atau bersama kelompok tani. Konsep penyuluhan seharusnya mendorong penyuluh pertanian bekerja bersama petani, karena dari hasil penelitian kuat sekali fakta yang menggambarkan betapa kuatnya kapasitas kelompok tani dalam mewujudkan interaksi partisipatif. Penyuluhan harus ditempatkan sebagai upaya menjembatani (bridging the gap) antara perilaku lama yang cenderung tidak berdaya, ke arah perilaku baru yang memberikan kemampuan mereka untuk merubah perilaku mereka sendiri. Dengan demikian pendekatan penyuluhan yang terlalu teknokratis (hanya berorientasi teknis budidaya) ke arah problematizing, sehingga mereka mandiri untuk mampu memecahkan masalah sesuai realitas yang dihadapi di lapangan. 


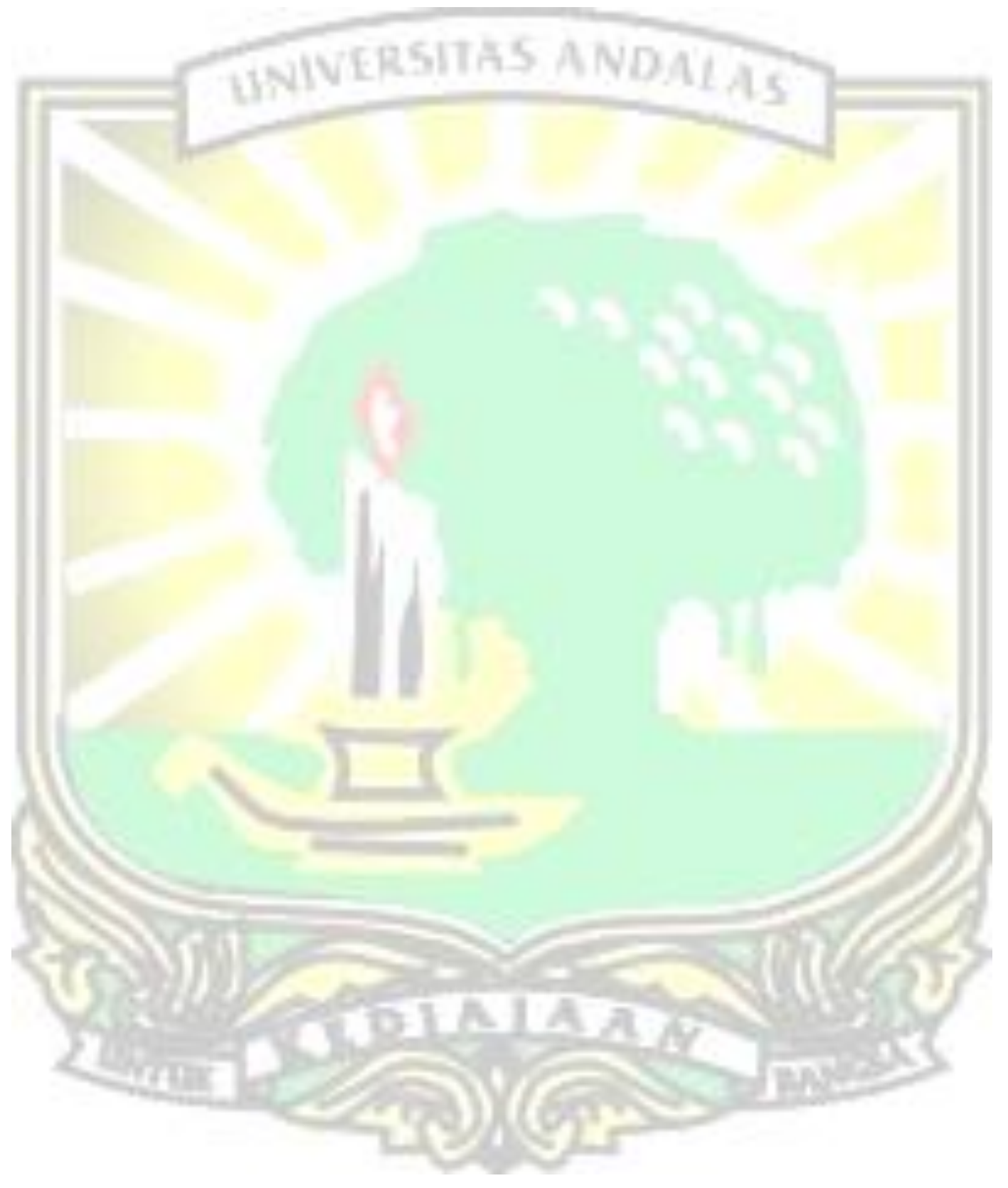




\title{
INTERAKSI PARTISIPATIF ANTARA PENYULUH PERTANIAN DAN KELOMPOK TANI MENUJU KEMANDIRIAN PETANI
}

\begin{abstract}
Joni Jafri ${ }^{1}$, Rudi Febriamansyah ${ }^{2}$, Rahmat Syahni $^{3}$, dan Asmawi ${ }^{4}$
ABSTRAK

Sebagian besar petani adalah petani berskala kecil, dengan kemampuan yang relatif lemah secara ekonomis, dan lemah dalam mengembangkan kapasitas dirinya. Menurut BPS tahun 2013 jumlah petani gurem (rumah tangga pertanian yang mengusahakan lahan pertanian kurang dari setengah hektar) sebanyak 14,25 juta rumah tangga atau sekitar 55,33 persen dari sekitar 26 juta rumah tangga pertanian. Rendahnya kapasitas petani secara keseluruhan semakin membutuhkan perhatian serius terhadap pengembangan sumber daya manusia (SDM) pertanian. Penelitian ini bertujuan untuk menganalisis faktor-faktor yang memengaruhi kapasitas penyuluh pertanian dan kapasitas kelompok tani dalam membangun interaksi sosial yang bersifat partisipatif antara penyuluh pertanian dan kelompok tani. Penelitian dilakukan di Kabupaten Merangin dan Kabupaten Kerinci, Provinsi Jambi, dengan total sampel sebanyak 180 orang, terdiri dari 36 orang penyuluh pertanian dan 144 orang petani. Data kualitatif yang dikumpulkan dianalisis-secara deskriptif-induktif, sementara data yang bersifat kuantitatif selanjutnya dianalisis-menggunakan program PLS (Partial Least Square). Hasil analisis menunjukkan bahwa interaksi partisipatif antara penyuluh pertanian dan kelompok tani secara nyata ditentukan oleh kapasitas penyuluh pertanian dan kapasitas kelompok tani. Kapasitas kelompok tani memberikan pengaruh lebih nyata terhadap interaksi partisipatif dibandingkan dengan kapasitas penyuluh pertanian. Rendahnya kapasitas penyuluh pertanian mengarah kepada rendahnya pencapaian penyuluhan pertanian yang partisipatif.
\end{abstract}

Kata Kunci: penyuluhan, pertanian, interaksi, kelompok tani 


\title{
Interaction between Agriculture Extention Officer and Farmers Group toward Farmers Resilience
}

\author{
Joni Jafri ${ }^{1}$, Rudi Febriamansyah ${ }^{2}$, Rahmat Syahni ${ }^{3}$, dan Asmawi ${ }^{4}$
}

\begin{abstract}
Most of the farmers are small-scaled farmers, economically weak and weak in building their capacities. According to BPS, in 2013 the small farmes (who just have the land less then 0,5 ha) are 14,25 million house hold,its about $55,3 \%$ of 26 million farmer's household. The overall low capacity of the farmers lead to the need of attention of human resource development seriously. The objective of this research was to analize the factors that can support the development of agriculture extension officer's capacity, the factors that can support the development of the farmer group's capacity, the lingkage partisipative interaction factor components between the agriculture extension officer and the farmer group. The research took place in Merangin Regency and Kerinci Regency, Jambi province. There were 180 samples which consisted of 36 persons Agricultural Extension (AE) officers and 144 farmers. The qualitative analysis used a descriptive-inductive approach, and quantitative analysis used PLS programme (Partial Least Square). The results showed that the participative interaction that happened was determined by the capacity of the agricultural extension officers and capacity of farmers group. The results also showed that the capacity of the farmers group was significantly influence the partisipative interaction, as to the capacity of the agricultural extension officers. The low agricultural extension officers capacity led to the low partisipative agricultural extension achievement.
\end{abstract}

Key Words: extention, agriculture, interaction, farmers group 